\title{
Challenging times for local government in Labor's new federation
}

\author{
Commonwealth Journal of Local Governance \\ Issue 1: May 2008 \\ http://epress.lib.uts.edu.au/ojs/index.php/cjlg
}

\author{
Graham Sansom \\ University of Technology, Sydney
}

\begin{abstract}
"Vice-chancellors have a responsibility to get down and say that we're prepared to reform the sector in the following sensible and constructive ways ... rather than going back in a traditional way and saying, 'Give us more money and leave us alone'. We will get nothing simply by asking for more money."
\end{abstract}

The Australian Labor Party went to the 2007 election promising a new era of cooperative federalism that would end the 'blame game' between federal and state governments and re-energise reform and productivity agendas. On the evidence of the Council of Australian Governments (COAG) meeting on 26 March 2008, these agendas are advancing rapidly. The communiqué foreshadowed a raft of new commonwealth-state agreements, streamlined arrangements for special purpose grants and, perhaps most significantly, performance criteria for payment of at least some of those grants. ${ }^{2}$

Local government, in the person of the president of the Australian Local Government Association (ALGA), has been a member of COAG since its inception. ${ }^{3}$ At the first meeting of COAG after last year's election, ALGA joined three new working groups - on infrastructure, housing and climate change. Another key area of COAG activity - reform of business regulation - addresses two core concerns for local government, namely development assessment and building control. These received detailed attention at the March meeting. In particular, COAG:

\footnotetext{
${ }^{1}$ Prof Ian Chubb of the Australian National University, quoted in The Sydney Morning Herald, 14 March 2008.

2 Communique of Council of Australian Governments' Meeting, Adelaide, 26 March 2008, viewed at http://www.coag.gov.au/meetings/260308/docs/communique20080326.rtf

${ }^{3}$ COAG consists of the prime minister, state premiers, territory chief ministers and the ALGA president.
} 
- noted the federal commitment of up to $\$ 30$ million to assist local councils across Australia to introduce electronic development assessment (eDA) systems

- requested the Local Government and Planning Ministers' Council to report back in July 2008 on the scope and timelines for taking the streamlining of processes further, options for fast-tracking the introduction of common performance measurement criteria, and progress with rapid adoption of eDA across local councils to help speed up land release and reduce development costs

- agreed that councils' systems must be implemented in an integrated and co-ordinated manner using national frameworks and standards, and that the national eDA data protocol that underpins these systems must be properly established and maintained

- sought a review of processes that apply to the Building Code of Australia (BCA) and removal of unnecessary state-based and local government variations to the BCA.

The revitalised COAG agenda thus poses major challenges for local councils to perform effectively, both in areas of core business and in addressing broader national priorities. Local government aspires to a stronger position in the federation through constitutional recognition and, according to the ALGA President "represents all Australians and delivers an increasingly broad range of services that make a difference to the lives of communities across our nation." ${ }^{, 4}$ So can local government demonstrate that it has a real contribution to make to national productivity, infrastructure improvement, housing affordability, Indigenous wellbeing, climate change, water reforms and other issues on the COAG agenda?

ALGA's position paper for the 2007 federal election did indeed address several of these critical national issues, notably aspects of infrastructure, climate change, water resources, urban sustainability and broadband access. In some cases it was able to highlight the positive steps already being taken by local councils. However, the 10-Point Plan to Reinvigorate Local Communities was dominated by calls for additional federal funding to enable local government to address its own financial problems. These included bids for an increase in untied financial assistance grants (FAGs) to $1 \%$ of Commonwealth taxation revenue (net of the goods and services tax which is transferred to the states), and for $\$ 1$ billion over 4 years to fund a community infrastructure renewal program.

The Labor Party's local government policy did not respond directly to either of these bids, although local councils will be able to apply for a share

\footnotetext{
${ }^{4}$ Australian Local Government Association, A 10-Point Plan to Reinvigorate Local Communities, Deakin ACT, September 2007.
} 
of a proposed Housing Affordability Fund to meet part of the cost of housing-related infrastructure. Responding recently to questions about local government funding, the new federal minister, Anthony Albanese, has pointed to the scale of existing federal support (over \$2.1bn per annum), and to the forthcoming Productivity Commission ${ }^{5}$ report on local government's own revenue raising capacity. ${ }^{6}$ It may well prove highly significant that the Commission's draft report found that over the last decade local government property taxes ('rates') have declined as a percentage of GDP, depriving councils of a potential $\$ 1.7 \mathrm{bn}$ in extra revenue, and that most councils across Australia have scope to increase rates within reasonable affordability limits. ${ }^{7}$

Local government tends to overlook the fact that there are two ways to address the 'vertical fiscal imbalance' in Australia's federal system (by which the federal government collects far more tax than it needs for its expenditure, whilst the states and to a much lesser extent local government need to spend more than they collect). The solution constantly promoted by local councils and their associations involves ever increasing federal grants, but the other way is to change the balance of taxation, in part by substantially increasing property rates. The Productivity Commission's report may suggest the latter path, and this could prove highly attractive to a federal government committed to lowering income tax rates whilst simultaneously cutting expenditure in order to curb inflationary pressures.

It remains true that many small (in terms of population) rural and remote councils have little or no scope to increase rates. However, rather than increased federal funding for all councils, this problem could be addressed by changing the way FAGs are distributed, as suggested in the 2003 House of Representatives report on cost shifting. ${ }^{8}$ Again, the new government may find such an option worth exploring.

Labor's election policies relating to local government involved the establishment of three new organizations: Infrastructure Australia, Regional Development Australia, and the Council of Australian Local Governments. Infrastructure Australia will be a broadly representative body that will formulate and review proposals for nationally significant projects: local government has been promised representation. The situation is less clear with Regional Development Australia: this agency will have a national board drawn from a national network of regional committees, based on the existing Area Consultative Committees that advise the federal government

\footnotetext{
5 The Productivity Commission is an independent advisory body which undertakes inquiries requested by the federal government.

6 See Local Government Focus, Vol 24, No.2, February 2008 p.1; and Local Agenda, Issue 15, March 2008 p.25 (NSW Local Government and Shires Associations).

7 Productivity Commission, Assessing Local Government Revenue Raising Capacity, Draft Research Report, Commonwealth of Australia, 2007.

${ }^{8}$ House of Representatives Standing Committee on Economics, Finance and Public Administration, Rates and Taxes: A Fair Share for Responsible Local Government, Parliament of the Commonwealth of Australia, Canberra, 2003.
} 
on regional issues and formulate projects for funding under various programs. ${ }^{9}$ However, whilst local government can be a significant player in these committees, it does not necessarily have a leading or major role.

The proposed Council of Australian Local Governments (CALG) will perhaps offer the greatest challenge to local government's national leadership. This is to be a consultative and advisory forum comprising senior federal ministers and a broad cross-section of local government representatives drawn from ALGA and the state/territory associations, the Council of Capital City Lord Mayors (CCCLM), regional bodies and other stakeholder organizations. ${ }^{10}$ It is intended to enable local government to discuss national issues directly with the federal government, including infrastructure and transport, regional development, housing affordability and, as a top priority, a process that may lead ultimately to constitutional recognition. ${ }^{11}$

Establishing CALG will create both opportunities and risks for local government. Until now, local government's interests at the national level have been pursued primarily through ALGA, which has been recognised by successive federal governments as its principal representative. This was demonstrated most clearly in the negotiation by the Keating Labor government of the Commonwealth-Local Government Accord, signed by the then Prime Minister and ALGA President in November 2005. The Accord achieved precisely what CALG is now charged to do - set out an agreed policy framework. However, it is debatable whether that could have been done with a somewhat disparate group of local government representatives around the table. State and territory local government associations have different priorities, as do groups such as CCCLM, the Seachange councils (who have already met separately with the federal treasurer ${ }^{12}$ ), Local Government Managers Australia (the peak body for senior management) and others. Will local government be able to present a coherent and united view on key issues, and reinforce its credentials as a valuable partner, or will CALG become a Tower of Babel?

Responding to the opportunity once again to pursue constitutional recognition will be another difficult test. ALGA has enthusiastically embraced this element of Labor policy and is planning a National Constitutional Summit in Melbourne in December 2008. The hard question is what form of recognition to seek: the wording defeated at the last referendum on this issue in 1988 would simply have required all states to legislate for a system of elected local government. This would not have lessened state control over councils, nor would it necessarily have brought about any change in underlying federal relations - and local government

\footnotetext{
${ }^{9}$ See $L G$ News, 27 March 2008, Hallmark Editions, viewed at http://www.lgcentre.com.au/

10 Senator Kate Lundy, speech to the Local Government Association of Queensland, 29

August 2007, viewed at http://www.katelundy.com.au/localgovernment.htm

11 See Local Agenda, Issue 15, March 2008 p.25.

12 See $L G$ News, 28 February 2008, viewed at http://www.lgcentre.com.au/
} 
has already gained federal funding as well as membership of COAG and other federal forums even without recognition. So should it now press for more far-reaching constitutional change in order to become a "truly equal partner"? ${ }^{13}$ The chances of gaining necessary bi-partisan support federally and in a majority of states for such a bold move look slim, given that it would challenge state authority. But is it worth taking the risk of another failed referendum aimed at merely 'symbolic' recognition?

If local government is to prosper under the new Labor government it will have to demonstrate its relevance, capacity and credibility in terms of the emerging federal agenda. Simply asserting that councils have an important role to play, and then asking for more money to help them perform, is an unlikely recipe for success. As the Productivity Commission's draft report suggests, there is a growing divide in Australian local government. On the one hand there is a group of perhaps 150 large, financially robust urban and regional councils that can do much to advance the wellbeing of local communities with little or no external support, and can also become significant partners in the federal system. On the other hand are the many (too many) small councils that in their current form will increasingly struggle to remain financially sustainable and can make only a very limited contribution to national objectives. The recent widespread amalgamations of councils in Queensland were explicitly designed to strengthen local government's capacity to deal with 'big picture' issues, ${ }^{14}$ and most of Australia's largest, most robust and (potentially at least) politically influential councils are now to be found in that state.

Local government thus faces a clear choice. It can continue to pursue an agenda of constitutional recognition and bids for additional financial support that tends to focus attention on its weaknesses and seems unlikely to achieve very much in the short-medium term. Or it can accept unpalatable structural and financial reforms to address the problems of small councils, whilst asserting and capitalising on its strengths, especially the real capacity of big councils to add value to federal initiatives.

\footnotetext{
13 ALGA President Cllr Paul Bell quoted in ALGA News, 14 March 2008, viewed at http://www.alga.asn.au

${ }^{14}$ Report of the Local Government Reform Commission - Volume 1, State of Queensland, July 2007.
} 